Article

\title{
Antioxidant Activity and Selenium and Polyphenols Content from Selected Medicinal Plants Natives from Various Areas Abundant in Selenium (Poland, Lithuania, and Western Ukraine)
}

\author{
Zofia Sotek ${ }^{1, *}$, Bożenna Białecka ${ }^{2}$, Bogumiła Pilarczyk ${ }^{3}$, Radosław Drozd ${ }^{4}$, Renata Pilarczyk ${ }^{5}$, \\ Agnieszka Tomza-Marciniak ${ }^{3}$, Barna Kruzhel ${ }^{6}$, Halyna Lysak ${ }^{6}$, Małgorzata Bąkowska ${ }^{3}$ \\ and Stakh Vovk ${ }^{7}$ (D) \\ 1 Institute of Marine and Environmental Sciences, University of Szczecin, Mickiewicza 18, \\ 70-383 Szczecin, Poland \\ 2 Molecular Biology and Biotechnology Center, Environmental Research Laboratory, University of Szczecin, \\ Małkocin 37, 73-110 Stargard, Poland; Bozenna.Bialecka@usz.edu.pl \\ 3 Department of Animal Reproduction Biotechnology and Environmental Hygiene, West Pomeranian \\ University of Technology in Szczecin, Janickiego 29, 71-270 Szczecin, Poland; \\ Bogumila.Pilarczyk@zut.edu.pl (B.P.); Agnieszka.Tomza-Marciniak@zut.edu.pl (A.T.-M.); \\ malgorzata.bakowska@zut.edu.pl (M.B.) \\ 4 Department of Immunology, Microbiology and Physiological Chemistry, West Pomeranian University of \\ Technology in Szczecin, Judyma 24, 71-466 Szczecin, Poland; radoslaw.drozd@zut.edu.pl \\ 5 Laboratory of Biostatistics, West Pomeranian University of Technology in Szczecin, Janickiego 29, \\ 71-270 Szczecin, Poland; renata.pilarczyk@zut.edu.pl \\ 6 Department of Biotechnology and Animal Science, Lviv National Agrarian University, 80381 Lviv-Dubljany, \\ Ukraine; Barna53@mail.ru (B.K.); Orhigea@gmail.com (H.L.) \\ 7 Institute of Agriculture of Carpathian, National Academy of Agrarian Sciences of Ukraine, Obroshyno, \\ Pustomyty, 81115 Lviv, Ukraine; vovkstah@gmail.com \\ * Correspondence: sotek@univ.szczecin.pl; Tel.: +48-(91)-444-1560
}

Received: 7 October 2019; Accepted: 21 November 2019; Published: 25 November 2019

Abstract: The study was performed on Centaurea cyanus, Chamomilla recutita, Majorana hortensis, Ocimum basilicum, Plantago lanceolata, Sinapis alba, and Valeriana officinalis harvested in Lithuania, Poland, and Ukraine. Our aim was to determine the differences in selenium concentrations, total polyphenols, and the antioxidant activity in same-species samples from different regions. Another goal was to assess the correlations between these variables within the species. We found variations in most species, but not in all regions of harvesting. In four of the six species from Ukraine, we observed the highest concentration of Se. The selenium concentrations ranged from 15-182 $\mu \mathrm{g} / \mathrm{kg}$ $\mathrm{DW}$, and the greatest variation between the regions occurred in S. alba. The level of polyphenols was 5.52-53.25 mg TAE/100 g DW, and the largest differences between the sampling regions occurred in $P$. lanceolata and O. basilicum. ABTS radicals scavenging ability ranged from 5.20-59.79 $\mu \mathrm{M} \mathrm{AAE} / 100$ g DW, while the FRAP potential was 13.56-409.14 $\mu \mathrm{M}$ FeE/100 g DW. The largest differences in antioxidant activity were found in O. basilicum and M. hortensis. Pearson's correlation coefficients indicate that polyphenols may be responsible for antioxidant activity in Ch. recutita, O. basilicum, and $V$. officinalis, and selenium is responsible for antioxidant activity in M. hortensis. However, both polyphenols and selenium play a role in the antioxidant properties of C. cyanus and P. lanceolata. Also, selenium in $C$. cyanus and $C h$. recutita may affect the level of total polyphenols. The examined species may supplement the human diet with exogenous antioxidants.

Keywords: herbs; selenium; ABTS; FRAP; polyphenols 


\section{Introduction}

In living organisms, endogenic antioxidants are not able to maintain redox balance if the level of free radicals is overabundant. This leads to oxidative stress, which may contribute to a damage in cellular and tissue structures. It also induces many degenerative diseases (cardiovascular disease, diabetes, Parkinson's disease, Alzheimer's disease, different kinds of cancer, AIDS) [1]. Exogenous antioxidants like polyphenols (flavonoids, phenolic acids, tannins, coumarins, and others), vitamin C (ascorbic acid) and E ( $\alpha$-tocopherol), carotenoids [2], antioxidative peptides [3], and some minerals including selenium (Se), found in food and/or dietary supplements, play an important role in fighting against oxidative stress.

The antioxidative properties of polyphenols comes from their ability to form stable phenoxy-radicals [2]. Polyphenols cause an increase in the activity of antioxidant enzymes: superoxide dismutase (SOD: EC 1.15.1.1), catalase (CAT: EC 1.11.1.6), and glutathione peroxidase (GPx: EC 1.11.1.19), but also affect the concentration of low-molecular antioxidants like ascorbic acid and $\alpha$-tocopherol [4].

In a human body, selenium is a crucial trace element, acting not only as an antioxidant, but also having anti-mutagenic, antiviral, and antineoplastic properties [5]. Two basic amino acids, selenomethionine and selenocysteine, are composed of selenium and build enzymes that are important for the human body (glutathione peroxidase and thioredoxin reductase) and have strong antioxidant properties. The amount of selenium in human body depends primarily on its abundance in the diet. It was estimated that for adults (of normal weight), the appropriate intake of selenium is $60 \mu \mathrm{g} / \mathrm{day}$ for women and $70 \mu \mathrm{g} /$ day for men [6]. A toxic effect may occur as a result of an excessive consumption of this element. For instance, with consumption of plant and animal food products obtained in the areas characterized by a high selenium abundance, concentrations reach as high as $350 \mathrm{mg} / \mathrm{kg}$ [7]. There are areas with high concentrations of selenium in soil, known as "Selenium provinces", like in Mexico, Columbia, and in some regions of the USA. However, the Se content in soil usually ranges from 0.1 to $2 \mathrm{mg} / \mathrm{kg}$, and its average level in the soils worldwide is $0.33 \mathrm{mg} / \mathrm{kg}$ [8]. Considerable dispersion of selenium is typical for soils created from landslide materials formed during glaciation periods [9], an example of which are the soils found in Poland and Lithuania. Specifically, particularly low levels of selenium are found in loose-sandy and loamy soils. The abundance of selenium in the human diet does not result from its concentration in soil, but rather from its bioavailability for plants (chemical forms, soil $\mathrm{pH}$, activity of microflora) and from climate conditions [10].

Plants are an important source of exogenous antioxidants, including polyphenols and selenium. These antioxidants are primarily found in fruits, vegetables, and herbs. These herbs are commonly used for their healing properties (including antibacterial, anticancer, hepatoprotective, anti-inflammatory, cardiac stimulant, sedative, and diastolic potential) and/or taste qualities include Centaurea cyanus and Chamomilla recutita (Asteraceae), Majorana hortensis i Ocimum basilicum (Lamiaceae), Plantago lanceolata (Plantaginaceae), Sinapis alba (Brasicaceae) i Valeriana officinalis (Valerianaceae). The use of herbal products results in positive effects on the treatment of diseases caused by free radicals [11]. For this reason, we have decided to undertake a study on the content of selenium and polyphenols and antioxidative potential in the selected species of herbs and popular spice plants collected in the areas diversified in abundance in selenium: Northern Poland, Lithuania, and Western Ukraine.

The aim of the study was: (i) To define and compare the concentration of selenium in plants and total polyphenols as well as the antioxidative activity in the same species of plants collected in different regions of the sample collection, and (ii) to assess the correlation between the concentration of selenium and total polyphenol and antioxidative properties of the individual species. 


\section{Materials and Methods}

\subsection{Plant Material}

The plant material used in the study consisted of inflorescence of Centaurea cyanus and Chamomilla recutita, leaves of Plantago lanceolata, herbs of Majorana hortensis and Ocimum basilicum, seeds of Sinapis alba, and roots of Valeriana officinalis. The herbs were collected in Northern Poland (Pomorze region-Połczyn Zdrój and Podlasie region-Koryciny), Western Ukraine, and in the case of the two first species, also in Southeastern Lithuania (Olita region-Lazdijai). Research material of the same species but of different regions was collected at the same optimal harvesting time that was recommended for the particular herb or spice. Usually, in each region, we collected 5 samples of each species at the same location, and only in Ch. recutita (Pomorze) and C. cyanus (Podlasie) we decided to collect 10 samples. The material was dried in natural conditions, and the plants of the same species collected at the same location were considered as a pool sample.

The plants collected in Poland and Lithuania grew on fawn soils with a granulometric composition of sandy loams formed on clay moraine sediments (Luvisols-the type of soil) [12-15], while in Ukraine, they grew on black-earth soils (chernozem) developed on loess basis [16] (Table 1). However, in Lithuania, the soils are acidic, while in Pomerania and Podlasie, they are slightly acidic, and in Ukraine, they are slightly alkaline. The regions of plant collection differed in selenium abundance [17]. Soils in Ukraine, in the neighborhood of Zabłotce, were characterized by a relatively high concentration of selenium, which ranged from 0.357 to $0.492 \mathrm{mg} / \mathrm{kg}$, whereas soils in Lithuania, in surroundings of Lazdija, showed a scarce supply of selenium $(<0.102 \mathrm{mg} / \mathrm{kg})$. The concentration of selenium was also low in Pomorze (Połczyn Zdrój) and Podlasie (Koryciny) and ranged between 0.102 and 0.245 mg/kg [17]. A similar difference was also found in the total amount of organic carbon (TOC): Ukraine 2.67-3.54 $\mathrm{wt} \%$, Poland (Pomorze and Podlasie) 1.16-1.53 wt\%, and Lithuania 0.500-0.661 wt\%) [18].

Table 1. Selected climatic factors and type of soil from areas of plant materials samples' collection ${ }^{1}$.

\begin{tabular}{|c|c|c|c|c|}
\hline \multirow[b]{2}{*}{ Climatic Factors } & \multirow{2}{*}{$\begin{array}{c}\text { Lithuania } \\
\begin{array}{c}\text { Olita Region } \\
\text { Lazdijai }\end{array}\end{array}$} & \multicolumn{2}{|c|}{ Poland } & \multirow{2}{*}{$\begin{array}{c}\text { Ukraine } \\
\begin{array}{c}\text { Lviv Region } \\
\text { Brody }^{2}\end{array}\end{array}$} \\
\hline & & $\begin{array}{l}\text { Pomorze Region } \\
\text { Połczyn Zdrój }\end{array}$ & $\begin{array}{l}\text { Podlasie Region } \\
\text { Koryciny }\end{array}$ & \\
\hline $\begin{array}{c}\text { Mean annual } \\
\text { precipitation }(\mathrm{mm})\end{array}$ & 593 & 649 & 560 & 602 \\
\hline $\begin{array}{l}\text { The highest mean } \\
\text { rainfalls }(\mathrm{mm}) \text { - month }\end{array}$ & $\begin{array}{c}81 \\
\text { July }\end{array}$ & $\begin{array}{c}82 \\
\text { July }\end{array}$ & $\begin{array}{c}75 \\
\text { July }\end{array}$ & $\begin{array}{c}87 \\
\text { July }\end{array}$ \\
\hline $\begin{array}{l}\text { The lowest mean } \\
\text { rainfalls }(\mathrm{mm}) \text { - month }\end{array}$ & $\begin{array}{c}22 \\
\text { February }\end{array}$ & $\begin{array}{c}30 \\
\text { February }\end{array}$ & $\begin{array}{c}28 \\
\text { February }\end{array}$ & $\begin{array}{c}31 \\
\text { January }\end{array}$ \\
\hline $\begin{array}{c}\text { Mean annual } \\
\text { temperature }\left({ }^{\circ} \mathrm{C}\right)\end{array}$ & 6.3 & 7.7 & 6.9 & 7.6 \\
\hline $\begin{array}{l}\text { The warmest month, } \\
\text { mean temperature }\left({ }^{\circ} \mathrm{C}\right)\end{array}$ & $\begin{array}{l}16.9 \\
\text { July }\end{array}$ & $\begin{array}{l}17.7 \\
\text { July }\end{array}$ & $\begin{array}{l}18.0 \\
\text { July }\end{array}$ & $\begin{array}{l}18.5 \\
\text { July }\end{array}$ \\
\hline $\begin{array}{l}\text { The coldest month, mean } \\
\text { temperature }\left({ }^{\circ} \mathrm{C}\right)\end{array}$ & $\begin{array}{l}\text { January } \\
-5.3\end{array}$ & $\begin{array}{c}\text { January } \\
-3.4\end{array}$ & $\begin{array}{l}\text { December } \\
-2.3\end{array}$ & $\begin{array}{l}\text { January } \\
-4.5\end{array}$ \\
\hline Type of soil & Luvisols & Luvisols & Luvisols & Chernozems \\
\hline
\end{tabular}

According to the Köppen-Geiger system, the regions of sample collection are classified into the same climatic category-Dfb: temperate continental climate/humid continental climate [19]. However, these areas sometimes differed significantly in terms of precipitation. The highest average annual rainfall was recorded nearby Połczyn Zdrój in Pomorze (649 mm), and the smallest in Koryciny in Podlasie (560 mm). Additionally, Olita in Lithuania was the coldest region. Not only were the lowest 
average annual temperatures recorded here, but also the lowest average temperatures of the warmest and coldest month (Table 1).

\subsection{Assessment of Selenium Concentration}

Selenium (Se) concentrations in herbs were determined using Watkinson's spectrofluorometric method [20], modified by Grzebuła and Witkowski [21]. The tissues were dissolved in $\mathrm{HNO}_{3}$ at $230{ }^{\circ} \mathrm{C}$ for $180 \mathrm{~min}$ and in $\mathrm{HClO}_{4}$ at $310{ }^{\circ} \mathrm{C}$ for $20 \mathrm{~min}$. Then, the samples were hydrolyzed with $9 \% \mathrm{HCl}$. Selenium was derivatized with 2,3-diaminonaphtalene (Sigma-Aldrich, St. Louis, MO, USA) and the complex was extracted into cyclohexane. The Se concentration was measured fluorometrically using a RF-5001 PC Shimadzu spectrophotofluorometer. The excitation wavelength was $376 \mathrm{~nm}$, and the fluorescence emission wavelength was $518 \mathrm{~nm}$.

The accuracy of the method for herbs was verified basing on the BCR-402 White clover certified reference material. The level of recovery was as $89 \%$ of the reference value.

\subsection{Sample Preparation for Total Polyphenol Content and Antioxidant Potential}

One hundred milligrams of each type of dried research material was pulverized with a mortar and a pestle, transferred to a $10 \mathrm{~mL}$ plastic tube, and filled to $5 \mathrm{~mL}$ with deionized water heated to $50^{\circ} \mathrm{C}$. The suspension was stirred vigorously and left for $45 \mathrm{~min}$ in the shade. Then, the tubes were centrifuged at $4{ }^{\circ} \mathrm{C}, 15,000 \mathrm{rpm}$, for $10 \mathrm{~min}$. The supernatant obtained in this procedure was used for further assays within $24 \mathrm{~h}$.

\subsection{Total Polyphenol (TP) Content Assay}

The total polyphenolic acid content of the extracts was determined using the Folin-Ciocalteu method, modified to a microplate reader format (Infinite M200pro, Tecan, Grödig, Austria) [22]. The total amount of polyphenolic compounds was expressed as $\mathrm{mg}$ of tannic acid equivalent per $100 \mathrm{~g}$ of dry weight (DW) of the sample (mg TAE/100 $\mathrm{g}$ DW).

\subsection{Free Radical ABTS Scavenging Ability Assay (ABTS)}

The free radical scavenging activity of water extracts was determined by the solution of ABTS cation radical discoloration assay, according to Shi et al. [23]. The assays were conducted with a microplate reader (Infinite M200pro, Tecan, Grödig, Austria). Further, $10 \mu \mathrm{L}$ of the sample was added to $300 \mu \mathrm{L}$ of ABTS working reagent, diluted to $0.7 \pm 0.02$ of absorbance at $734 \mathrm{~nm}$. Next, the initial absorbance was read immediately, while the final absorbance was measured after $6 \mathrm{~min}$. As a standard for method calibration we used ascorbic acid. The percent of ABTS radical inhibition was calculated according to Formula (1).

$$
\% \text { inhibition }=\left[\mathrm{A}_{0}-\left(\mathrm{A}_{\mathrm{f}}-\mathrm{B}\right)\right] / \mathrm{A}_{0} \times 100
$$

where $A_{0}$ is the absorbance of control at $t=0 \mathrm{~min} ; A_{f}$ is the absorbance of sample after $6 \mathrm{~min}$; $B$ is the absorbance of blank sample.

The results were expressed in equivalents of $\mu \mathrm{M}$ ascorbic acid per $100 \mathrm{~g}$ DW ( $\mu \mathrm{M}$ AAE/100 g DW).

\subsection{Ferric Reducing Antioxidant Power Assay (FRAP)}

The FRAP method, modified to the microplate reader format (Infinite M200pro, Tecan, Grödig, Austria) [24], was used for the antioxidants potential assay. The FRAP working reagent was prepared by mixing acetate buffer $\left(300 \mu \mathrm{M}, \mathrm{pH}\right.$ 3.6) with $10 \mathrm{mM}$ TPTZ in $40 \mathrm{mM} \mathrm{HCl}$ solution, and $20 \mathrm{mM} \mathrm{FeCl}_{3}$ at a 10:1:1 (v/v/v) ratio. Next, $10 \mu \mathrm{L}$ of sample solutions were added to $300 \mu \mathrm{L}$ of the working reagent and preheated to $37^{\circ} \mathrm{C}$. The absorbance was measured at $593 \mathrm{~nm}$, after $6 \mathrm{~min}$. A standard curve was drawn for different concentrations of $\mathrm{FeCl}_{2}$ ranging from 1 to $0.1 \mathrm{mM}$. The antioxidant status was expressed as $\mu \mathrm{M} \mathrm{Fe}^{2+}$ equivalent per 100 of DW of sample ( $\mu \mathrm{M} \mathrm{FeE/100} \mathrm{g} \mathrm{DW).}$

All samples in all experiments were assayed in triplicate. 


\subsection{Statistical Analysis}

The results were analyzed statistically with STATISTICA 12.5 PL software (StatSoft Inc., Tulsa, OK, USA). The Shapiro-Wilk test was used to evaluate the distribution of the variables. If the variables were not normally distributed, the logarithm of the variables was calculated for further statistical analysis. One-way ANOVA was performed, and the significance of differences between the mean values from the different regions were calculated using the parametric Tukey's test. Differences were considered significant at $p \leq 0.01$. A correlation between the concentration of selenium and polyphenols, potential to deactivate cation radicals (ABTS), and reducing antioxidant power (FRAP) were assessed by calculating the Pearson's correlation coefficient. Statistical significance of the correlation coefficients was tested at $p \leq 0.05$.

\section{Results}

\subsection{Selenium (Se)}

The concentration of selenium ranged from $15 \mu \mathrm{g} / \mathrm{kg}$ DW in M. hortensis from Pomorze to $182 \mu \mathrm{g} / \mathrm{kg}$ DW in S. alba from Podlasie (Figure 1). In the plants of these two species, a significant difference in the accumulation of Se was found for all sample collection regions. In Ch. recutita, the concentration of tested trace element did not differ significantly only in plants from Lithuania and Pomorze. On the other hand, in C. cyanus, only plants collected in Ukraine differed significantly in the level of Se in comparison to other regions. In O. basilicum, P. lanceolate, and V. officinalis, no significant differences in Se level between the sample collection regions were found.

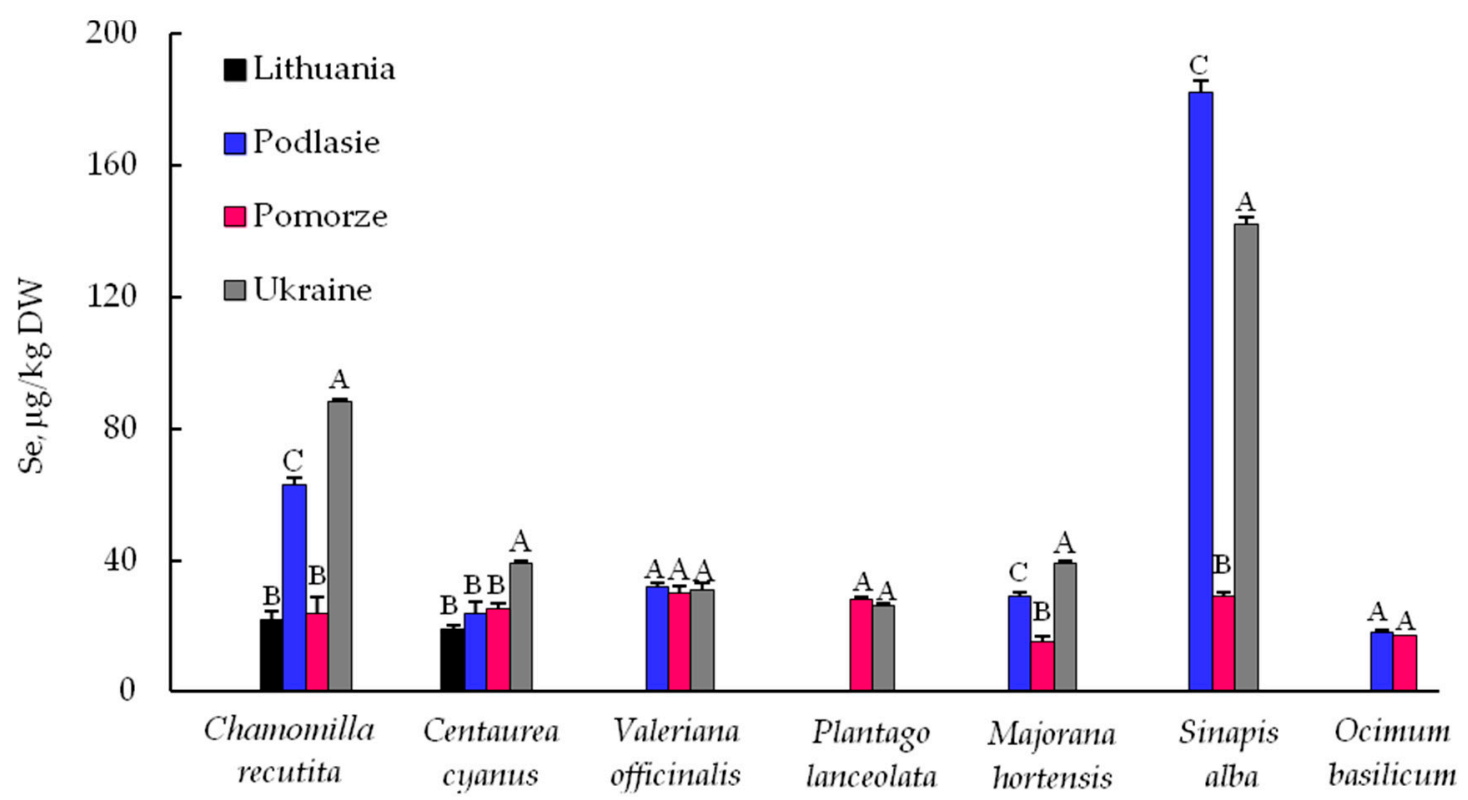

Figure 1. The concentration of selenium (Se) in herbs from Lithuania, Poland: Podlasie, Pomorze, and Ukraine. Vertical bars indicate mean from three measurements \pm SEM (standard error of measurement). Different letters indicate statistically significant differences at $p \leq 0.01$ within a species.

\subsection{Total Polyphenols}

The total content of polyphenols in samples from different regions was from $5.52 \pm 0.115 \mathrm{mg}$ TAE/100 g DW in V. officinalis to $53.25 \pm 0.049 \mathrm{mg}$ TAE/100 g DW in P. lanceolata, both from Ukraine (Figure 2). All the examined species except M. hortensis and S. alba, differed significantly in the total concentration of polyphenols in every region of sample collection $(p \leq 0.01)$. 


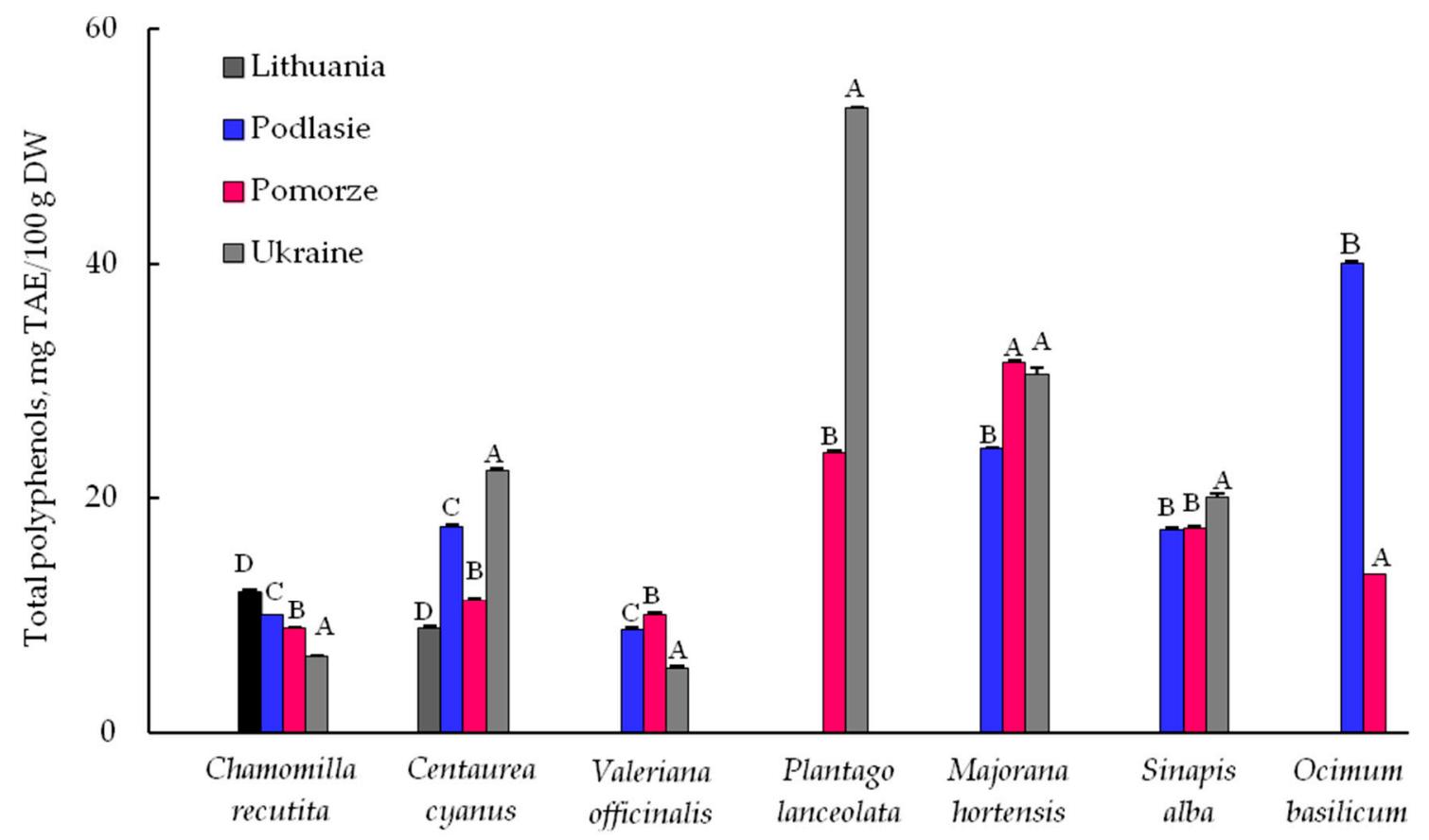

Figure 2. The concentration of total polyphenols (TP) in herbs from Lithuania, Poland: Podlasie, Pomorze, and Ukraine. Vertical bars indicate mean from three measurements \pm SEM (standard error of measurement). Different letters indicate statistically significant differences at $p \leq 0.01$ within a species.

\subsection{ABTS Radicals Scavenging Ability of Plant Extracts}

The ABTS cation radical scavenging activity in the examined plants from different regions of sampling ranged from $5.20 \pm 0.176 \mu \mathrm{M}$ AAE/100 g DW in C. cyanus from Lithuania to $59.79 \pm 0.137 \mu \mathrm{M}$ $\mathrm{AAE} / 100 \mathrm{~g}$ DW in O. basilicum from Podlasie (Figure 3). In all the species except P. lanceolata, we found significant differences in ABTS radicals scavenging ability between some regions of sample collection $(p \leq 0.01)$, while the highest diversification in activity was observed in Ch. recutita and O. basilicum.

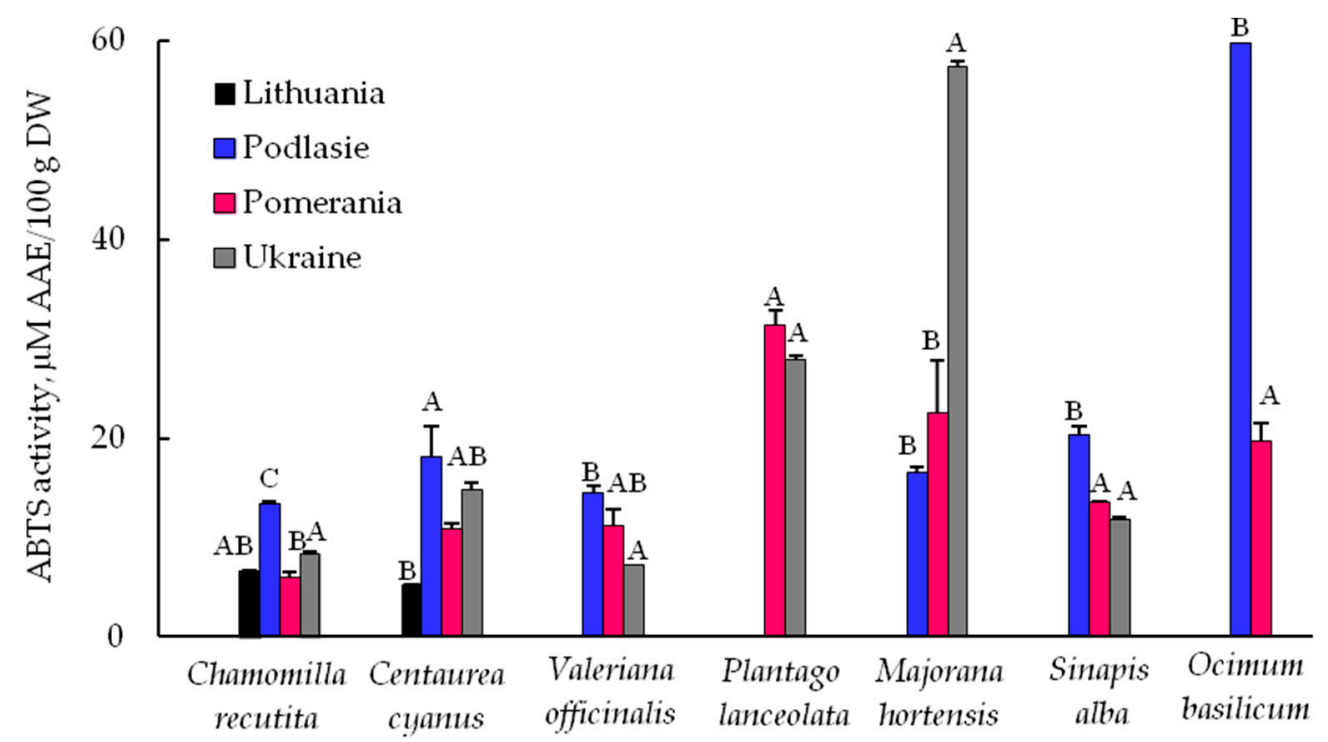

Figure 3. The ABTS radicals scavenging ability in herbs from Lithuania, Poland: Podlasie, Pomorze, and Ukraine. Vertical bars indicate mean of three measurements \pm SEM (standard error of measurements). Different letters indicate statistically significant differences at $p \leq 0.01$ within a species. 


\subsection{FRAP Activity}

Ferric reducing antioxidant power in the tested plants from all regions of sample collection ranged from $13.56 \pm 0.147 \mu \mathrm{M} \mathrm{FeE} / 100 \mathrm{~g}$ DW in Ch. recutita from Ukraine to $409.14 \pm 0.460 \mu \mathrm{M} \mathrm{FeE} / 100 \mathrm{~g}$ DW in O. basilicum from Podlasie (Figure 4). We found significant differences in FRAP between the regions of sample collection in all the examined species except $C$. cyanus and Ch. recutita $(p \leq 0.01)$. In C. cyanus, the significant differences were noted only between plants from Podlasie and Lithuania, while in Ch. recutita, we found no differences in FRAP in these exact regions.

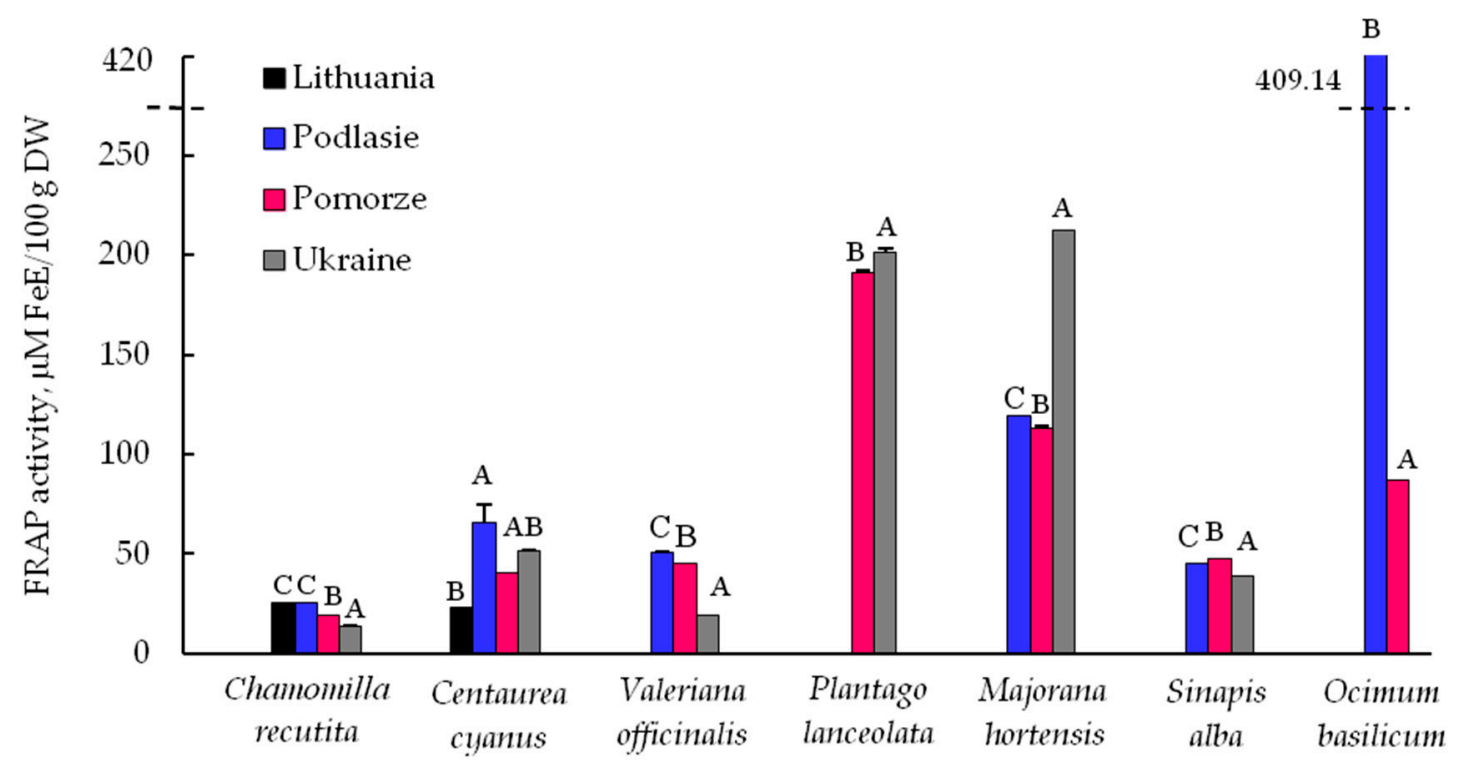

Figure 4. The ferric reducing antioxidant power assay (FRAP) activity in herbs from Lithuania, Poland: Podlasie, Pomorze, and Ukraine. Vertical bars indicate mean of three measurements \pm SEM (standard error of measurement). Different letters indicate statistically significant differences at $p \leq 0.01$ within a species.

\subsection{Correlations Between Selenium, Polyphenol, and ABTS Radicals Scavenging Ability and FRAP Activity}

The analysis of Pearson correlation (R) was used to explain the relationship between selenium and total polyphenol content, and antioxidative activity measured with ABTS radicals scavenging and FRAP methods for all the analyzed plants of particular species (Table 2). A significant positive correlation between concentration of Se and ABTS radicals scavenging and FRAP potential was observed in C. cyanus and M. hortensis. In P. lanceolata, Ch. recutita, and S. alba, we found a significant positive correlation between the levels of Se and ABTS radicals scavenging. We also found a significant negative correlation between Se and FRAP potential in the last two species. Only in C. cyanus, a significant positive correlation was found between the levels of selenium and total polyphenols. The correlation between these two parameters in Ch. recutita had an opposite character. Significant positive correlation between the level of total polyphenols and ABTS radicals scavenging and FRAP potential was noted in O. basilicum, C. cyanus, and V. officinalis. In turn, a significant positive correlation between the total polyphenol concentration and FRAP potential was observed in Ch. recutita and P. lanceolata. Only S. alba experienced a significant negative correlation between total polyphenols and ABTS radicals scavenging and FRAP activity. 
Table 2. Pearson correlation ( $\mathrm{R}$ - coefficient) between selenium (Se), total polyphenols (TP) content, and antioxidant assays (ABTS and FRAP).

\begin{tabular}{cccccccc}
\hline \multirow{2}{*}{ Parameter } & \multicolumn{9}{c}{ Herbs } & \multicolumn{2}{c}{ Spices } \\
\cline { 2 - 8 } & $\begin{array}{c}\text { Centaurea } \\
\text { cyanus }\end{array}$ & $\begin{array}{c}\text { Chamomilla } \\
\text { recutita }\end{array}$ & $\begin{array}{c}\text { Plantago } \\
\text { lanceolata }\end{array}$ & $\begin{array}{c}\text { Valeriana } \\
\text { officinalis }\end{array}$ & $\begin{array}{c}\text { Majorana } \\
\text { hortensis }\end{array}$ & $\begin{array}{c}\text { Ocimum } \\
\text { basilicum }\end{array}$ & $\begin{array}{c}\text { Sinapis } \\
\text { alba }\end{array}$ \\
\hline Se \& ABTS & $0.656^{* * *}$ & $0.429^{*}$ & $0.689^{*}$ & $\mathrm{~ns}$ & $0.691^{* *}$ & $\mathrm{~ns}$ & $0.551^{*}$ \\
Se \& FRAP & $0.607^{* * *}$ & $-0.413^{*}$ & $\mathrm{~ns}$ & $\mathrm{~ns}$ & $0.821^{* * *}$ & $\mathrm{~ns}$ & $-0.557^{*}$ \\
Se \& TP & $0.626^{* * *}$ & $-0.619^{* * *}$ & $\mathrm{~ns}$ & $\mathrm{~ns}$ & $\mathrm{~ns}$ & $\mathrm{~ns}$ & $\mathrm{~ns}$ \\
TP \& ABTS & $0.537^{* *}$ & $\mathrm{~ns}$ & $\mathrm{~ns}$ & $0.519^{*}$ & $\mathrm{~ns}$ & $0.990^{* * *}$ & $-0.671^{* *}$ \\
TP \& FRAP & $0.527^{* *}$ & $0.915^{* * *}$ & $0.818^{* *}$ & $0.901^{* * *}$ & $\mathrm{~ns}$ & $0.999^{* * *}$ & $-0.880^{* * *}$ \\
\hline
\end{tabular}

Significance level: ${ }^{* *} p \leq 0.001,{ }^{* *} p \leq 0.01,{ }^{*} p \leq 0.05$, ns-no significant.

\section{Discussion}

The content of selenium in plants depends not only on the abundance of this element in the ground, but largely on its bioavailability pronounced by its chemical form, $\mathrm{pH}$ and redox potential of soil, presence of organic substances, activity of soil microorganisms, and climatic factors as well [10,25].

In the case of Ch. recutita, C. cyanus, and $M$. hortensis, plants from Ukraine contained significantly more selenium than those growing in Poland and Lithuania (Figure 1). Undoubtedly, this was influenced by the type of soil and its abundance in selenium (Table 1, see Section 2.1). Soils in Ukraine, in the region of plant harvesting, are the chernozems. Compared to the luvisols found in harvesting regions in northern Poland and Lithuania, the chernozem is characterized by, e.g., a higher percentage of humus and a slightly alkaline $\mathrm{pH}$. They show a greater selenium content, which is positively correlated with the amount of organic carbon [18]. Higher $\mathrm{pH}$ levels promote the formation of selenates (VI), which are the most absorbable form of Se for plants. This fact probably explains the highest level of selenium in the aforementioned species found in Ukraine. In soils of Northern Poland and Lithuania with a slightly acidic or acidic $\mathrm{pH}$, the availability of Se may be lower, since acidification leads to the formation of sparingly soluble and poorly digestible selenides and elemental selenium [26]. Higher Se levels in samples from Western Ukraine compared to the material collected in Northern Poland were previously also observed in Calendula officinalis, Mentha x piperita, and Sylibum marianum [27].

In $C h$. recutita, $M$. hortensis, and $S$. alba, a significantly lower Se content was found in plants harvested in Pomerania than in Podlasie, despite the fact that both regions are classified in the same soil category, in the terms of Se abundance [15]. The soils from the sample collection areas in all these regions belong to the same type, and therefore differences in selenium accumulation in plants of the same species may be caused by other factors, e.g., the climate. However, in this specific case, the level of selenium does not seem to be influenced by temperature, and although it is an important climatic factor playing a role in Se intake by plants, its long-term data only slightly differ in these two regions (Table 1). However, the difference in the amount of average annual precipitation is clear, as they are nearly $90 \mathrm{~mm}$ higher in Pomorze. During the periods of intense rainfall, easily soluble selenium compounds can be leached out of the soil. In addition, Se will be less absorbed in wet areas as it creates poorly soluble iron compounds in such conditions [28].

The content of selenium in plants also depends on the species and variety, as well as on its developmental stage and part, because this element in various stages of plant development is accumulated in its particular organs to varying degrees [29,30]. It has been proved that in medical plant material, fruits and seeds contain the most selenium [31]. In our study, in S. alba seeds (although not in all the regions of collection), the highest average selenium content was found, compared to the other tested plant samples (Figure 1). S. alba seeds from Podlasie and Ukraine turned out to be particularly rich in Se. Much less of this element was found in seeds from Pomerania. This indicates that S. alba seeds can accumulate Se widely and also be a rich source of it. S. alba belongs to the Brassicaceae family, in which some of the species are considered to be accumulators or even hyper accumulators (e.g., Stanleya pinnata) of this bioelement [32-34]. However, not all of the analyzed species showed 
a relationship between Se accumulation and the location, because within O. basilicum, P. lanceolata, and $V$. officinalis, no differences were found in samples originating from different regions (Figure 1).

The examined species in general differed in levels of total polyphenols between all the regions of sample collection (Figure 2). The exceptions were M. hortensis and S. alba, in which the differences occurred only between some regions. In C. cyanus, P. lanceolata, and S. alba, the highest content of polyphenols was found in plants harvested in Ukrainian chernozem, rich in organic compounds. The polyphenol content depends on the plant species and results from the variations in edaphoclimatic conditions of the growing sites (e.g., soil composition, water availability, and sunlight exposure), which may influence the formation of these compounds [35,36]. The concentration of polyphenols in O. basilicum from Pomerania and Podlasie (Figure 2) was lower than in the other species of the Lamiaceae family-Mentha x piperita, obtained in the same regions [27]. An analogous relationship regarding the level of total polyphenols between O. basilicum and M. x piperita was observed in the Czech Republic [37]. Plants of the Lamiaceae family are known as a rich source of polyphenolic compounds and are popular for their good antioxidant properties [38].

Plants of the same species but from different regions of sample collection generally showed differentiated antioxidant potential, wherein the variation was greater for FRAP than for ABTS radicals scavenging ability (Figures 3 and 4). The highest value of antioxidative potential, regardless of the test method, was found in O. basilicum from Podlasie and was proportional to the content of total polyphenols. A similar relationship, but only with respect to DPPH and polyphenols, was found in this species in Romania [39]. M. hortensis from Ukraine and P. lanceolata from Ukraine and Pomerania also were characterized by a high antioxidative activity (Figures 3 and 4 ).

Polyphenols are probably the main components responsible for antioxidative activity in Ch. recutita, $O$. basilicum, and $V$. officinalis, which is indicated by a positive significant Pearson rank correlation measured between the total polyphenols level and FRAP and/or ABTS radicals scavenging ability (Table 2, Scheme A1). A linear relationship between the total polyphenols content and antioxidant potential has been found in plants of these species before [40-42]. In M. hortensis, however, it is likely that Se is strongly associated with the antioxidant properties. This can be demonstrated by the high (ABTS) and very high (FRAP) correlation of selenium levels with antioxidant potential. Both polyphenols and selenium have an effect on the antioxidant properties of $C$. cyanus and P. lanceolata, but to varying degrees (Scheme A1). In P. lanceolata, it is probably the polyphenols that play a decisive role (Table 2, Scheme A1). Our research is in line with previous observations made on plants of this species in Romania [43]. In C. cyanus, antioxidant activity is more correlated with selenium than with total polyphenols (Table 2), and therefore polyphenols may not be the main compounds responsible for the antioxidant activity of this species (Scheme A1). Some other selenium-induced compounds, e.g., ascorbic acid, can play this role. Erol-Dayi et al. [44] pointed out the lack of role of polyphenols as free radical scavenging constituents in Centaurea spp. obtained in Turkey. The negative significant and high correlation in S. alba noted in our research is in opposition to the results obtained by Thangi et al. [45], who observed a positive high correlation between the content of polyphenols and antioxidant activity in seeds of this species from India.

Our results also suggest that selenium in some species may have a positive (C. cyanus) or negative (Ch. recutita) effect on the total polyphenols level, which is reflected in the values of Pearson correlation coefficients (Table 2). It has been shown that exogenous selenium stimulated the level of phenolic compounds in broccoli and Lycopersicon esculentum [46-48]. It can cause abiotic stress, which stimulates the synthesis of polyphenol compounds [49].

\section{Conclusions}

Our research showed that the variations in Se concentration, total polyphenols, and antioxidant properties are noticeable in most plant species, but not in every collection region. The type of soil and its abundance in selenium could have played a decisive role in the concentration of this element in Ch. recutita, C. cyanus, M. hortensis, and S. alba. In the case of samples collected in different 
regions on the same soil type and with a similar Se content, the amount of rainfall could have an effect on the concentration of this element in plants. For example, it was noticeable in Ch. recutita, C. cyanus, and S. alba harvested in Pomerania and Podlasie. The higher concentrations of total polyphenols in C. cyanus, P. lanceolata, M. hortensis, and S. alba from Ukraine could be caused by the type of soil found there, which is rich in organic matter. The results suggest that the antioxidant properties of $C h$. recutita, $O$. basilicum, and $V$. officinalis are clearly associated with polyphenols, in $M$. hortensis with selenium, and in C. cyanus and P. lanceolata with both selenium and polyphenols.

Author Contributions: Z.S.—conceptualization, resources and materials, data analysis, writing-original draft preparation; B.B.-data analysis, writing-original draft preparation; B.P.-conceptualization, methodology, investigation, writing - review; R.D.—-methodology, investigation, writing-review; R.P.—statistical data analysis data analysis, writing — review; A.T.-M.—investigation, writing—review; B.K.-resources and materials, writing-review; H.L.-resources and materials, writing-review; M.B.-investigation, writing-review; S.V.- - resources and materials, writing-review. The listed authors have contributed substantially to this work.

Funding: This research received no external funding. The APC was funded by the University of Szczecin as part of individual research grants.

Acknowledgments: We would like to thank Mirosław Angielczyk from "Ziołowy Zakatek" in Koryciny for sharing the research material used in this study. We are also grateful to the anonymous reviewers for their constructive comments that have allowed us to significantly improve on the first manuscript version, and to Dominic Bueno for English correction.

Conflicts of Interest: The authors declare no conflict of interest.

\section{Appendix A}

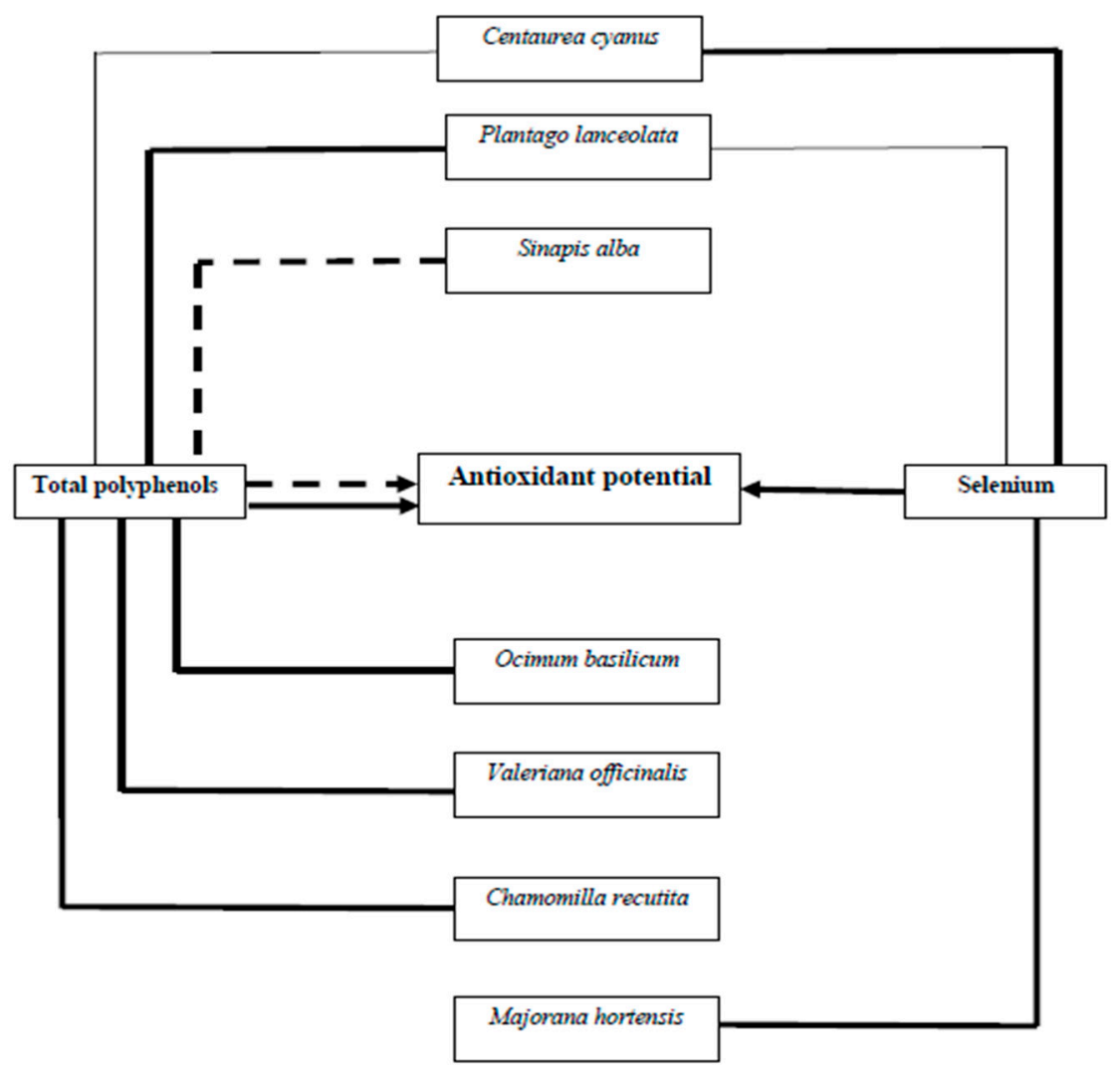

Scheme A1. The role of selenium and total polyphenols in the antioxidant potential of Centaurea cyanus, Chamomilla recutita, Majorana hortensis, Ocimum basilicum, Plantago lanceolata, Sinapis alba and Valeriana officinalis. Plant species were connected with the factors responsible for their antioxidant potential with continuous lines. The thickness of the line corresponds to the strength of the parameter in influencing the antioxidant activity of the species. The dashed line indicates a parameter that negatively affects the antioxidant potential. 


\section{References}

1. Reuter, S.; Gupta, S.C.; Chaturvedi, M.M.; Aggarwal, B.B. Oxidative stress, inflammation, and cancer: How are they linked? Free Radic. Biol. Med. 2010, 49, 1603-1616. [CrossRef] [PubMed]

2. Masella, R.; Di Benedetto, R.; Varì, R.; Filesi, C.; Giovannini, C. Novel mechanisms of natural antioxidant compounds in biological systems: Involvement of glutathione and glutathione-related enzymes. J. Nutr. Biochem. 2005, 16, 577-586. [CrossRef] [PubMed]

3. Sarmadi, B.H.; Ismail, A. Antioxidative peptides from food proteins: A review. Peptides 2010, 31, $1949-1956$. [CrossRef] [PubMed]

4. Matés, J.M.; Pérez-Gómez, C.; De Castro, I.N. Antioxidant enzymes and human diseases. Clin. Biochem. 1999, 32, 595-603. [CrossRef]

5. Schrauzer, G.N. Selenium and selenium-antagonistic elements in nutritional cancer prevention. Crit. Rev. Biotechnol. 2009, 29, 10-17. [CrossRef]

6. Kipp, A.P.; Strohm, D.; Brigelius-Flohé, R.; Schomburg, L.; Bechthold, A.; Leschik-Bonnet, E.; Heseker, H. Revised reference values for selenium intake. J. Trace Elem. Med. Biol. 2015, 32, 195-199. [CrossRef]

7. Oldfield, J.E. Selenium World Atlas: Updated Edition; Selenium-Tellurium Development Association: Grimbergen, Belgium, 2002; pp. 1-59.

8. White, P.J.; Bawen, H.C.; Parmaguru, P.; Fritz, M.; Spracklen, W.P.; Spiby, R.E.; Meacham, M.C.; Meam, A.; Harriman, M.; Trueman, L.J.; et al. Interactions between selenium an sulfur nutrition in Arabidopsis thaliana. J. Exp. Bot. 2004, 55, 1927-1937. [CrossRef]

9. Piotrowska, M. Zawartość selenu w uprawnych glebach Polski. Rocz. Glebozn. 1984, 35, $23-31$.

10. Terry, N.; Zayed, A.M.; De Souza, M.P.; Tarun, A.S. Selenium in higher plants. Annu. Rev. Plant Biol. 2000, 51, 401-432. [CrossRef]

11. Sen, S.; Chakraborty, R.; Sridhar, C.; Reddy, Y.S.R.; De, B. Free radicals, antioxidants, diseases and phytomedicines: Current status and future prospect. Int. J. Pharm. Sci. Rev. Res. 2010, 3, 91-100.

12. Iuss Working Group Wrb. World Reference Base for Soil Resources 2014: International Soil Classification System for Naming Soils and Creating Legends for Soil Maps; World Soil Resources Report; FAO: Rome, Italy, 2014.

13. Pustelnikovas, O. Geoekologiczna ocena składu chemicznego gleb i osadów rzecznych na tle jednostek geomorfologicznych Litwy. Landf. Anal. 2008, 9, 96-103.

14. Miklaszewski, S. Mapa gleb Litwy 1:1500 000. Dosw. Rol. 1927, 3-4, 1-33.

15. Białousz, S. Mapa gleb Polski 1: 1500 00. Gleby-Klasyfikacja genetyczna. In Atlas Rzeczypospolitej Polskiej; PAN: Warszawa, Poland, 1994.

16. Voronina, A.V. Soil Map of Ukraine 1:2 500 000; General Directorate of Surveying and Cartography of the Soviet Ministry, GUGK: Moscow, USSR, 1977.

17. Reimann, C.; Birke, M.; Demetriades, A.; Filzmoser, P.; O'Connor, P. Chemistry of Europe's Agricultural Soils; Geologisches Jahrbuch (Reihe B); Schweizerbart Science Publishers: Stuttgart, Germany, 2014; Volume 102, pp. 1-523.

18. Birke, M.; Reimann, C.; Demetriades, A.; Dinelli, E.; Rauch, U.; The GEMAS Project Team. Geochemical mapping at European scale-the GEMAS-project. In Proceedings of the International Workshop on Groundwater Systems in Europe, Berlin, Germany, 22-23 August 2013.

19. Peel, M.C.; Finlayson, B.L.; Mcmahon, T. Updated world map of the Köppen-Geiger climate classification. Hydrol. Earth Syst. Sci. 2007, 4, 439-473. [CrossRef]

20. Watkinson, J.H. Fluorometric determination of selenium in biological material with 2,3-Diaminonaphthalene. Anal. Chem. 1966, 38, 92-97. [CrossRef]

21. Grzebuła, S.; Witkowski, P. The determination of selenium trace levels in biological materials with fluorometric method. Selenium determination in tissues and bodily fluids. Pol. Arch. Weter 1977, 20, 125-138. (In Polish)

22. Anastasiadi, M.; Pratsinis, H.; Kletsas, D.; Skaltsounis, A.L.; Haroutounian, S.A. Bioactive non-coloured polyphenols content of grapes, wines and vinification by-products: Evaluation of the antioxidant activities of their extracts. Food Res. Int. 2010, 4, 805-813. [CrossRef]

23. Shi, F.; Jia, X.; Zhao, C.; Chen, Y. Antioxidant activities of various extracts from Artemisisa selengensis Turcz (LuHao). Molecules 2010, 15, 4934-4946. [CrossRef]

24. Benzi, I.F.F.; Strain, J.J. The ferric reducing ability of plasma (FRAP) as a measure of "antioxidant power": The FRAP assay. Anal. Biochem. 1996, 239, 70-76. [CrossRef] 
25. Kabata-Pendias, A.; Pendias, H. Trace Elements in Soils and Plants, 3rd ed.; CRC Press: Boca Raton, FL, USA; London, UK; New York, NY, USA; Washington, DC, USA, 2001; pp. 1-403.

26. Zabłocki, Z. Selen w Glebach i Roślinach Pomorza Zachodniego. Ph.D. Thesis, Agricultural Academy of Szczecin, Szczecin, Poland, 1990.

27. Sotek, Z.; Białecka, B.; Pilarczyk, B.; Kruzhel, B.; Drozd, R.; Pilarczyk, R.; Tomza-Marciniak, A.; Lysak, H.; Bakowska, M.; Vovk, S. The content of selenium, polyphenols and antioxidative activity in selected medicinal plants from Poland and Western Ukraine. Acta Pol. Pharm. Drug Res. 2018, 75, 1107-1116.

28. Čuvardić, M.S. Selenium in soil. Matica Srp. Proc. Nat. Sci. 2003, 104, 23-37. [CrossRef]

29. Pezzarossa, B.; Petruzzelli, G.; Petacco, F.; Malorgio, F.; Ferri, T. Absorption of selenium by Lactuca sativa as affected by carboxymethylcellulose. Chemosphere 2007, 67, 322-329. [CrossRef] [PubMed]

30. Bitterli, C.; Bañuelos, G.S.; Schulin, R. Use of transfer factors to characterize uptake of selenium by plants. J. Geochem. Explor. 2010, 107, 206-216. [CrossRef]

31. Ulewicz-Magulska, B.; Wesołowski, M. A chemometric approach to distribution of selenium in medicinal plants cultivated in Poland. J. Med. Food 2013, 16, 460-466. [CrossRef] [PubMed]

32. Bañuelos, G.S.; Ajwa, H.A.; Mackey, B.; Wu, L.; Cook, C.; Akohoue, S.; Zambruzuski, S. Evaluation of different plant species used for phytoremediation of high soil selenium. J. Environ. Qual. 1997, 26, 639-646. [CrossRef]

33. Galeas, M.L.; Zhang, L.H.; Freeman, J.L.; Wegner, M.; Pilon-Smits, E.A.H. Seasonal fluctuations of selenium and sulfur accumulation in selenium hyperaccumulators and related non-accumulators. New Phytol. 2007, 173, 517-525. [CrossRef] [PubMed]

34. Harris, L.W.; Elliott, T.L.; Davies, T.J. Community restructuring can maintain diversity across a severity gradient in the absence of foundation species. Ecosphere 2014, 5, 1-16. [CrossRef]

35. Igamberdiev, A.U.; Bykova, N.V. Role of organic acids in the integration of cellular redox metabolism and mediation of redox signalling in photosynthetic tissues of higher plants. Free Radic. Biol. Med. 2018, 122, 74-85. [CrossRef]

36. Lopez-Bucio, J.; Nieto-Jacobo, M.F.; Ramırez-Rodriguez, V.; Herrera-Estrella, L. Organic acid metabolism in plants: From adaptive physiology to transgenic varieties for cultivation in extreme soils. Plant Sci. 2000, 160, 1-13. [CrossRef]

37. Chrpova, D.; Kourimska, L.; Gordon, M.H.; Hermanova, V.; Roubickova, I.; Panek, J. Antioxidant activity of selected phenols and herbs used in diets for medical conditions. Czech J. Food Sci. 2010, 28, 317-325. [CrossRef]

38. El-Lateef Gharib, A.; Teixeira da Silva, J.A. Composition, total phenolic content and antioxidant activity of the essential oil of four Lamiaceae herbs. Med. Aromat. Plant Sci. Biotechnol. 2013, 7, 19-27.

39. Benedec, D.; Vlase, L.; Hanganu, D.; Oniga, I. Antioxidant potential and polyphenolic content of Romanian Ocimum basilicum. Dig. J. Nanomater. Biostruct. 2012, 7, 1263-1270.

40. Javanmardi, J.; Stushnoff, C.; Locke, E.; Vivanco, J.M. Antioxidant activity and total phenolic content of Iranian Ocimum accessions. Food Chem. 2003, 83, 547-550. [CrossRef]

41. Pilerood, S.A.; Prakash, J. Evaluation of nutritional composition and antioxidant activity of Borage (Echium amoenum) and Valerian (Valerian officinalis). J. Food Sci. Technol. 2014, 51, 845-854. [CrossRef] [PubMed]

42. Elmastas, M.; Cinkilic, S.; Aboul-Enein, H.Y. Antioxidant capacity and determination of total phenolic compounds in daisy (Matricaria chamomilla, Fam. Asteraceae). World J. Anal. Chem. 2015, 3, 9-14. [CrossRef]

43. Nichita, C.; Neagu, G.; Cucu, A.; Vulturescu, V.; Vifor, Ş.; Berteşteanu, G. Antioxidative properties of Plantago lanceolata L. extracts evaluated by chemiluminescence method. AgroLife Sci. J. 2016, 5, 95-102.

44. Erol-Dayi, Ö.; Pekmez, M.; Bona, M.; Aras-Perk, A.; Arda, N. Total phenolic contents, antioxidant activities and cytotoxicity of three Centaurea species: C. calcitrapa subsp. calcitrapa, C. ptosimopappa and C. spicata. Free Rad Antiox 2011, 1, 31-36. [CrossRef]

45. Thangi, J.; Shashitha, K.N.; Ashwini, H.A.; Schlini, P. A correlation study of antioxidant potential's from Synapis alba. IAJPS 2016, 3, 234-239.

46. Bachiega, P.; Salgado, J.M.; de Carvalho, J.E.; Ruiz, A.L.T.G.; Schwarz, K.; Tezotto, T.; Morzelle, M.C. Antioxidant and antiproliferative activities in different maturation stages of broccoli (Brassica oleracea Italica) biofortified with selenium. Food Chem. 2016, 190, 771-776. [CrossRef] 
47. Robbins, R.J.; Keck, A.S.; Banuelos, G.; Finley, J.W. Cultivation conditions and selenium fertilization alter the phenolic profile, glucosinolate, and sulforaphane content of broccoli. J. Med. Food 2005, 8, 204-214. [CrossRef]

48. Schiavon, M.; dall'Acqua, S.; Mietto, A.; Pilon-Smits, E.A.H.; Sambo, P.; Masi, A.; Malagoli, M. Impact of selenium fertilization on chemical composition and antioxidant constituents of tomato (Solanum lycopersicon L.). J. Agric. Food Chem. 2013, 61, 10542-10554. [CrossRef]

49. Dutta, R.K.; Maharia, R.S. Antioxidant responses of some common medicinal plants grown in copper mining areas. Food Chem. 2012, 131, 259-265. [CrossRef]

(C) 2019 by the authors. Licensee MDPI, Basel, Switzerland. This article is an open access article distributed under the terms and conditions of the Creative Commons Attribution (CC BY) license (http://creativecommons.org/licenses/by/4.0/). 